\title{
SASAT 1. \\ Hal: 253-265 \\ PENGARUH KOMISARIS INDEPENDEN DAN KOMITE AUDIT TERHADAP PENGURANGAN ASIMETRI INFORMASI DISEKITAR PENGUMUMAN LABA
}

\author{
Evi Gantyowati \\ Fakultas Ekonomi Universitas Negeri Surakarta \\ Dhinar Adi Nugroho \\ Fakultas Ekonomi Universitas Negeri Surakarta \\ e-mail: Adzuf06@yahoo.com
}

\begin{abstract}
This research examine the impact of Independent Commissioner and Independent Audit Committee to reduces information asymmetry around earnings announcement. The sample of this research is the firms that included Indonesian Capital Market Directory (ICMD) 2007. Based on purposive sampling method, the sample is 86 firms during the period of 20042006. The results of this research show that independent commissioner has a significant impact to the reducing of asymmetry information. Independent Audit Committee is not indicate has an impact and a correlation to asymmetric information, like the independent commissioner. There is no differences in asymmetric information between firms with independent audit committee and none.
\end{abstract}

Keywords: Independent Commissioner, Independent Audit Committee, Asymmetry Information, Earnings Announcement, Trading Volume Activity (TVA)

\section{PENDAHULUAN}

Good Corporate Governance mendapat perhatian banyak pihak selama dekade terakhir. Perhatian itu disebabkan tiga hal, yang pertama adanya kecenderungan diversifikasi dan perluasan entitas yang memerlukan pemisahan pemilik dan manajemen. Kedua, adanya perubahan teknologi yang mendorong kebutuhan dana dari pihak lain dan penggunaan para profesional dalam manajemen entitas. Ketiga, perkembangan pasar modal yang menyediakan dana dan mengakibatkan munculnya kepemilikan minoritas publik.

Penelitian yang dilakukan oleh Asian Development Bank (ADB) menyimpulkan penyebab krisis ekonomi di negara-negara Asia, termasuk Indonesia, adalah (1) mekanisme pengawasan dewan komisaris (board of director) dan komite audit (audit committee) suatu perusahaan tidak berfungsi dengan efektif dalam melindungi kepentingan pemegang saham dan (2) pengelolaan perusahaan yang belum profesional. Oleh karena itu penerapan konsep GCG di Indonesia diharapkan dapat meningkatkan profesionalisme dan kesejahteraan pemegang saham tanpa mengabaikan kepentingan stakeholders.

Sunarto (2003) menyatakan bahwa corporate governance merupakan sebuah struktur, proses, budaya dan sistem untuk menciptakan kondisi operasional yang sukses bagi suatu organisasi. Sunarto (2003) menyatakan bahwa mekanisme corporate governance yang baik dan proporsi kepemilikan serta proporsi board of directors yang relatif seimbang akan dapat 
menciptakan good corporate governance (GCG). Apabila GCG tercapai, maka kinerja saham perusahaan tersebut akan semakin meningkat, meliputi ROE yang lebih tinggi, profit margin yang lebih tinggi, dan membayar kas deviden yang lebih. (Moksin, 2007).

Dalam rangka pelaksanaan tata kelola perusahaan yang baik, pemerintah telah mengeluarkan beberapa peraturan antara lain Bapepam dengan Surat Edaran No. SE03/PM/2000 yang mengatur tentang pembentukan dewan komisaris independen dan komite audit. Peraturan mewajibkan perusahaan tercatat memiliki komite audit. Komite audit harus beranggotakan minimal tiga orang independen dan salah satunya memiliki keahlian dalam bidang akuntansi. Salah seorang anggota komite audit harus berasal dari komisaris independen, yang merangkap sebagai ketua komite audit.

Salah satu ciri perusahaan yang dikelola dengan baik (good corporate governance) adalah menyampaikan informasi dengan lebih cepat, akurat, dan lengkap (Arifin, 2003). Suatu informasi dianggap informatif, jika informasi tersebut mampu mengubah kepercayaan para pengambil keputusan.

Corporate Governance menekankan pengendalian dan prosedur yang ada untuk meyakinkan bahwa manajemen bertindak untuk kepentingan pemilik. Penelitianpenelitian sebelumnya (lihat Kanagaretnam dkk, 2007) menunjukkan bahwa Dewan Komisaris yang memonitor manajemen lebih efektif, akan meningkatkan kualitas dan frekuensi informasi yang diterbitkan manajemen.

Teori keagenan mengimplikasikan adanya asimetri informasi antara manajer sebagai agen dan pemilik (dalam hal ini adalah pemegang saham) sebagai prinsipal. Asimetri informasi muncul ketika manajer lebih mengetahui informasi internal dan prospek perusahaan di masa yang akan datang dibandingkan pemegang saham dan stakeholder lainnya. dikaitkan dengan peningkatan nilai perusahaan, ketika terdapat asimetri informasi, manajer dapat memberikan sinyal mengenai kondisi perusahaan kepada investor guna memaksimisasi nilai saham perusahaan. Sinyal yang diberikan dapat dilakukan melalui pengungkapan (disclosure) informasi akuntansi.

Trading Volume Activity (TVA) sebagai indikator variabel volume perdagangan saham, digunakan untuk melihat apakah investor secara individual menilai laporan keuangan sebagai sesuatu yang informatif, dalam arti dengan informasi tersebut investor dapat membuat keputusan perdagangan di atas normal. Perbedaaan penting antara pengujian harga dan volume adalah bahwa harga merefleksikan perubahan dalam pengharapan pasar sebagai suatu keseluruhan sedangkan volume merefleksikan perubahan dalam pengharapan investor secara individual (Bandi dan Hartono, 1999). Suatu informasi, misalnya pengumuman laba atau pengumuman dividen mungkin netral dalam arti tidak mengubah pengharapan tentang pasar sebagai suatu keseluruhan tetapi mungkin mengubah pengharapan investor secara individual. Dalam situasi seperti ini, tidak akan ada reaksi harga, tetapi mungkin ada pergantian dalam posisi portofolio yang merefleksikan reaksi volume.

Fungsi Komisaris adalah mengawasi kinerja manajemen perusahaan agar perusahaan berjalan sesuai dengan harapan pemilik. Dengan tingginya tingkat independensi dari komisaris akan berdampak pada tingginya tingkat pengawasan terhadap manajemen, sehingga terdapat peningkatan voluntary disclosure yang menyebabkan terjadi penurunan asimetri informasi. Hal tersebut merupakan hal yang positif di mata investor karena informasi yang sampai ke tangan investor memiliki nilai kepercayaan 
yang lebih yang baik guna pengambilan keputusan.

Berdasar teori sinyal, pihak manajemen memberikan sinyal kondisi perusahaan melalui pengumuman atau publikasi informasi seperti pelaporan laba, pengumuman deviden, dan corporate action lain. Informasi tersebut disikapi investor dengan reaksi dalam pasar modal. Reaksi ini dapat membuat perubahan dalam harga atau pun volume saham. Jika reaksi investor baik dan memiliki dampak positif pada perdagangan saham, akan terjadi perubahan harga atau volume saham yang diperdagangkan. Pengambilan keputusan oleh investor untuk bereaksi dikarenakan informasi yang didapat dirasa memiliki nilai yang tinggi dan dapat dipercaya. Informasi yang informatif tersebut tentunya terkait dengan pengawasan komisaris dan komite audit.

Berdasarkan penelitian Asian Development Bank di atas dan masih adanya perbedaan hasil penelitian antara Fama (1980) dalam Eng dan Mak (2003) dan Kanagaretnam dkk (2007). Kanagaretnam dkk (2007) menyatakan bahwa komisaris independen merupakan sentral mekanisme kontrol internal perusahaan dalam melakukan pengawasan terhadap manajer. Eng dan Mak (2003) menyatakan semakin banyak jumlah anggota independen pada komisaris, mengurangi pengungkapan sukarela perusahaan, maka penelitian ini dilakukan.

Penelitian ini mengembangkan penelitian yang dilakukan oleh Kanagaretnam dkk (2007) yang menguji apakah good corporate governance menurunkan asimetri informasi di sekitar pengumuman laba triwulanan. Ada beberapa hal yang menyebabkan penelitian ini berbeda dengan penelitian sebelumnya. Pertama, penelitian ini menggunakan sampel perusahaan yang terdaftar di Bursa Efek Indonesia 2003 2007 dan menerbitkan laporan laba rugi tahunan tahun 2004-2006. Kedua, good corporate governance didasarkan pada aturan Bapepem-Surat Edaran No. SE03/PM/2000. Ketiga, proksi untuk asimetri informasi adalah selisih Trading Volume Activity pada periode window dengan periode non window. Proksi ini berdasarkan penelitian Hua dkk (2006), sedangkan Kanagaretnam dkk (2007) menggunakan ask bid spread.

Tujuan penelitian yang hendak dicapai adalah: Untuk mendapatkan bukti empiris mengenai pengaruh keberadaan Komisaris Independen dan komite audit terhadap penurunan asimetri informasi dan perbedaan asimetri informasi antara perusahaan yang mempunyai anggota komite audit dengan yang tidak mempunyai anggota komite audit.

Adapun kontribusi penelitian ini memberikan manfaat dan masukan kepada perusahaan yang terdaftar di Bursa Efek Indonesia untuk mendorong penerapan good corporate governance (GCG) sehingga pihak yang mempunyai kepentingan terhadap perusahaan dapat terlindungi dan harapan investor akan tingkat pengembalian (return) saham yang ditanamkan di perusahaan tersebut dapat dipertahankan. Selain itu bagi investor dapat mempertimbangkan keputusan investasinya berdasarkan pada perusahan yang telah menerapkan good corporate governance (GCG).

\section{TINJAUAN PUSTAKA}

Konsep corporate governance timbul karena adanya keterbatasan dari teori keagenan dalam mengatasi masalah keagenan dan dapat dipandang sebagai kelanjutan dari teori keagenan. Good corporate governance (GCG) merupakan sistem yang mampu memberikan perlindungan dan jaminan hak kepada stakeholders. Patricia Aburdene dalam majalah SWA (2006) menyatakan bahwa saat ini dan di masa depan, para stakeholders semakin kritis dan memiliki fungsi kontrol yang sangat kuat atas 
perusahaan. Para stakeholders yang meliputi para pemegang saham, karyawan, pemerintah, LSM, konsumen, dan masyarakat hanya mau menghargai perusahaan yang dikelola secara transaparan dan bertanggung jawab sosial.

Penerapan corporate governance yang efektif pada Bank, BUMN dan perusahaan publik, memberikan sumbangan yang penting dalam memperbaiki kondisi perekonomian, serta menghindari terjadinya krisis dan kegagalan serupa di masa mendatang. Salah satu ciri perusahaan yang dikelola dengan baik (good corporate governance) adalah menyampaikan informasi dengan lebih cepat, akurat, dan lengkap (Arifin, 2003).

Agar penyelenggaraan corporate governance dapat berjalan dengan baik (good corporate governance), pemerintah telah mengeluarkan beberapa peraturan antara lain Bapepam dengan Surat Edaran No. SE-03/PM/2000 mensyaratkan bahwa "setiap perusahaan publik di Indonesia wajib membentuk Komite Audit dengan anggota minimal 3 orang yang diketuai oleh satu orang komisaris independen perusahaan dengan dua orang eksternal yang independen terhadap perusahaan serta menguasai dan memiliki latar belakang akuntansi dan keuangan". Sementara bagi perusahaan BUMN/ BUMD, sesuai dengan keputusan Menteri Badan Usaha Milik Negara No. 117/M-MBU/2002 menyatakan bahwa "Komisaris/ Dewan Pengawas harus membentuk komite yang bekerja secara kolektif dan berfungsi membantu Komisaris/ Dewan Pengawas dalam melaksanakan tugasnya, yaitu membantu Komisaris/ Dewan Pengawas dalam memastikan efektivitas sistem pengendalian intern, efektivitas pelaksanaan tugas auditor eksternal dan auditor internal". Komite Audit berperan dalam pengeluaran statemen terkait resiko-resiko yang dihadapi perusahaan. Bisa disebut bahwa Komite Audit merupakan alat bagi banyak pihak untuk menghindari kecurangan dalam pelaporan keuangan.

Berdasar Pedoman Komisaris Independen dalam FCGI, komisaris independen merupakan pihak yang tidak terafiliasi dengan pemegang saham pengendali, anggota direksi dan dewan komisaris lain, dan perusahaan itu sendiri baik dalam bentuk hubungan bisnis maupun kekeluargaan. Yang dimaksud dengan terafiliasi di sini adalah tidak adanya hubungan keluarga, hubungan antara pihak dengan pegawai, direktur, atau komisaris dari pihak tersebut, hubungan antara dua perusahaan dimana terdapat satu atau lebih anggota direksi atau dewan komisaris yang sama, hubungan antar dua perusahaan yang dikendalikan baik langsung atau pun tidak langsung, dan hubungan antara perusahaan dan pemegang saham utama.

Salah satu fungsi utama dari komisaris independen adalah untuk menjalankan fungsi monitoring yang bersifat independen terhadap kinerja manajemen perusahaan. Keberadaan komisaris dapat menyeimbangkan kekuatan pihak manajemen (terutama CEO) dalam pengelolaan perusahaan melalui fungsi monitoringnya.

Dengan proporsi anggota independen yang besar dalam struktur dewan komisaris, akan memberikan efek pengawasan yang lebih baik dan dapat membatasi perluangpeluang kecurangan pihak manajerial (Eng dan Mak, 2003).

Komite Audit terdiri dari individuindividu yang mandiri dan tidak terlibat dengan tugas sehari-hari dari manajemen yang mengelola perusahaan, dan yang memiliki pengalaman untuk melaksanakan fungsi pengawasan secara efektif. Tanggung jawab komite audit antara lain memilih auditor independen, mengawasi proses audit, dan meyakinkan integritas dari pelaporan keuangan. Terdapat dua keuntungan monitoring potensial yang didapat dari memberikan tanggung jawab tersendiri 
kepada komisi ini, yaitu independensi dan efisiensi dewan.

Independensi dan integritas monitoring dapat meningkat dengan adanya laporan dari internal dan eksternal auditor kepada dewan yang terdiri dari outside director. Bukan kepada seluruh BOD karena di dalamnya terdapat CEO yang kinerjanya menjadi pertanyaan oleh auditor.

Komite ini dapat membantu menaikkan tingkat efisiensi dari fungsi Dewan itu sendiri. Hal ini menjadi sangat penting jika ukuran dari Dewan tersebut besar. Komite audit merupakan pihak akhir yang memonitor proses pelaporan keuangan perusahaan dan mereka akan mempengaruhi kebijakan yang diambil perusahaan berkaitan dengan prinsip yang digunakan dalam pelaporan keuangan.

Urgensi keberadaan komite audit ada pula kaitannya dengan belum optimalnya peran pengawasan yang diemban dewan komisaris di banyak perusahaan di negaranegara korban krisis yang lalu. Indonesia khususnya semakin diperparah dengan adanya karakteristik umum yang melekat pada entitas bisnis kita berupa pemusatan kontrol atau pengendalian kepemilikan perusahaan di tangan pihak tertentu atau segelintir pihak saja.

Earnings atau laba merupakan komponen keuangan yang menjadi pusat perhatian sekaligus dasar pengambilan keputusan bagi pihak-pihak yang berkepentingan. Laporan keuangan merupakan sarana pengkomunikasian informasi keuangan kepada pihak-pihak di luar korporasi. Teori keagenan (Agency Theory) mengimplikasikan adanya asimetri informasi antara manajer sebagai agen dan pemilik (dalam hal ini adalah pemegang saham) sebagai prinsipal. Asimetri informasi muncul ketika manajer lebih mengetahui informasi internal dan prospek perusahaan di masa yang akan datang dibandingkan pemegang saham dan stakeholder lainnya dikaitkan dengan peningkatan nilai perusahaan, ketika terdapat asimetri informasi, manajer dapat memberikan sinyal mengenai kondisi perusahaan kepada investor guna memaksimisasi nilai saham perusahaan.

Isu corporate governance muncul karena terjadi pemisahan antara kepemilikan (di pihak investor/ principal) dengan pengelolaan (manajer/ agent) suatu perusahaan, yang dapat menimbulkan masalah keagenan (agency problem). Hubungan keagenan adalah sebuah kontrak antara principal dan agent. Jensen dan Meckling (1976) memandang baik principal dan agent merupakan pemaksimum kesejahteraan sehingga ada kemungkinan besar bahwa agen tidak selalu bertindak demi kepentingan terbaik principal.

Perspektif hubungan keagenan merupakan dasar yang digunakan untuk memahami corporate governance. Corporate governance yang merupakan konsep yang didasarkan pada teori keagenan, diharapkan bisa berfungsi sebagai alat untuk memberikan keyakinan kepada para investor bahwa mereka akan menerima return atas dana yang telah mereka investasikan. Corporate governance berkaitan dengan bagaimana para investor yakin bahwa manajer akan memberikan keuntungan bagi mereka, yakin bahwa manajer tidak akan mencuri atau menginvestasikan ke dalam proyekproyek yang tidak menguntungkan berkaitan dengan dana/ kapital yang telah ditanamkan oleh investor, dan berkaitan dengan bagaimana para investor mengontrol para manajer (Ujiyantho dan Pramuka, 2007).

Teori keagenan mengimplikasikan adanya asimetri informasi antara manajer sebagai agen dan pemilik (dalam hal ini adalah pemegang saham) sebagai prinsipal. Asimetri informasi muncul ketika manajer lebih mengetahui informasi internal dan prospek perusahaan di masa yang akan datang dibandingkan pemegang saham dan stakeholder lainnya. dikaitkan dengan pe- 
ningkatan nilai perusahaan, ketika terdapat asimetri informasi, manajer dapat memberikan sinyal mengenai kondisi perusahaan kepada investor guna memaksimisasi nilai saham perusahaan.

Menurut teori sinyal, terdapat asimetri informasi antara manajer dan investor. Manajer mengetahui prospek perusahaan di masa depan, sedangkan investor tidak. Setiawan dan Subekti (2005) membuktikan bahwa dividen merupakan suatu sinyal yang baik untuk menyampaikan maksud perusahaan kepada investor. Pengumuman dividen dapat digunakan investor untuk memperkecil asimetri informasi dengan manajer, sehingga pengumuman dividen merupakan informasi yang berguna untuk pengambilan keputusan. Oleh karena itu, pengumuman dividen mempunyai kandungan informasi yang berguna bagi investor. Demikian pula dengan laporan yang dipublikasikan lainnya, misalnya laporan laba.

Semenjak trading volume menjadi faktor yang fundamental menaikkan nilai pasar dan berhubungan dengan likuiditas, kekuatan untuk mengendalikan trading volume ini menjadi topik yang menarik dalam keuangan (Chae, 2002). Menurut Widayanti (2005), Trading Volume Activity (TVA) merupakan instrumen yang dapat digunakan untuk melihat reaksi pasar modal terhadap informasi melalui parameter pergerakan aktivitas volume perdagangan saham di pasar modal. Perubahan volume perdagangan saham di pasar modal menunjukkan aktivitas perdagangan saham di bursa dan mencerminkan keputusan investasi investor.

Harga sekuritas terjadi setelah adanya keseimbangan antara permintaan dan penawaran sekuritas. Permintaan dan penawaran ini juga berhubungan dengan jumlah lembar saham yang diperdagangkan. Jumlah lembar saham yang terjadi dalam transaksi inilah yang disebut sebagai volume perdagangan. Pengamatan terhadap volume perdagangan biasanya menggunakan indikator Trading Volume Activity (TVA).

Trading Volume Activity (TVA) digunakan untuk melihat apakah investor secara individual menilai laporan keuangan informatif, dalam arti apakah dengan informasi tersebut membuat keputusan perdagangan di atas normal (Wuryanti, 2004). Di dalam TVA tidak memisahkan antara informasi positif (pembelian) maupun informasi negatif (penjualan).

Dalam beberapa penelitian sebelumnya mengenai pengumuman laba dan pengumuman-pengumuman perusahaan lainnya, sepertinya terdapat asimetri informasi yang tinggi sebelum pengumuman. Pengumuman laba merupakan salah satu bentuk pengumuman yang dilakukan perusahaan. Pengumuman laba ini tidak hanya direspon oleh investor yang memiliki informasi saja, akan tetapi investor yang tidak memiliki informasi perusahaan pun, akan melakukan reaksi ketika pengumuman laba. Karena tiap pelaku pasar berpandangan akan ada informasi penting yang disampaikan ke pasar oleh perusahaan (Chae, 2002).

Atiase dan Bamber (1994) menemukan bahwa terdapat hubungan positif antara volume perdagangan pada pengumuman laba, dengan asimetri informasi. Chae (2002) menemukan bahwa penurunan asimetri informasi terjadi hanya sebelum adanya pengumuman laba.

Penelitian mengenai corporate governance dan atau suatu peristiwa (event) yang informasinya dipublikasikan sebagai suatu pengumuman sudah banyak dilakukan. Pengumuman tersebut dianggap memiliki kandungan informasi apabila pasar bereaksi pada saat pengumuman tersebut diterima oleh pasar.

Salah satu bagian penelitian Kanagaretman dkk (2007) menunjukkan perusahaan yang semakin besar prosentase komisaris independennya, rata-rata kenaikan ask-bid 
spread-nya secara signifikan semakin mengecil di sekitar pengumuman laba. Secara umum penelitian ini menyimpulkan bahwa kualitas good corporate menurunkan asimetri informasi di sekitar pengumuman laba.

Keberadaan Komisaris Independen memiliki pengaruh terhadap penurunan asimetri informasi di sekitar tanggal pengumuman laba. Hal ini menunjukkan bahwa komisaris independen merupakan sentral mekanisme kontrol internal perusahaan dalam melakukan pengawasan terhadap manajer (Fama, 1980). Ajinkya dkk; Karamanou dan Vafeas; Klein; dalam Kanagaretnam, 2007 menyatakan Dewan Komisaris yang memonitor manajemen lebih efektif, akan meningkatkan kualitas dan frekuensi informasi yang diterbitkan manajemen. Peningkatan voluntary disclosure akan menurunkan asimetri informasi. Dikarenakan semakin kecilnya celah informasi antara pihak eksternal dan internal perusahaan. Hal tersebut berbeda dengan temuan Eng dan Mak (2003) yang menyatakan semakin banyak jumlah anggota independen pada komisaris, mengurangi pengungkapan sukarela perusahaan.

Berdasarkan konsep dan hasil penelitian-penelitian di atas maka kami rumuskan hipotesis sebagai berikut:

$\mathrm{H}_{1}$ : Terdapat pengaruh keberadaan anggota komisaris independen terhadap penurunan asimetri informasi di sekitar tanggal pengumuman laba.

Penelitian Klien (2001); DeFond dan Jiambalvo (1991); McMulen (1996); Beasly dan Salterio (2001); McMullen dan Raghunandan (1996) mendukung keberadaan komite audit yang dapat meningkatkan kualitas pelaporan keuangan. Hal ini menandakan investor telah melihat nilai lebih pada perusahaan yang mempunyai komite audit independen. Sedangkan penelitian yang dilakukan oleh Beasley
(1996); Kalbers (1992); Crowford (1987) di dalam McMullen (1996) dan juga Menon dan Williams (1994), menunjukkan tidak adanya perbedaan antara perusahaan yang memiliki komite audit independen dengan yang tidak. Yang menandakan ketidakpercayaan investor terhadap kemampuan komite audit dalam meningkatkan kualitas laporan keuangan.

$\mathrm{H}_{2}$ : Terdapat pengaruh keberadaan anggota komite audit independen terhadap penurunan asimetri informasi di sekitar tanggal pengumuman laba.

\section{METODE PENELITIAN}

Populasi dalam penelitian ini adalah semua perusahaan yang terdaftar di Bursa Efek Indonesia yang melaporkan laba tahunan pada tahun 2004 - 2006. Data yang digunakan dalam penelitian ini adalah data sekunder.

Teknik pengambilan sampel dalam penelitian ini ditentukan berdasarkan purposive sampling method. Kriteria yang digunakan untuk memilih sampel dalam penelitian ini, adalah:

1. Perusahaan terdaftar di Bursa Efek Indonesia pada tahun 2003-2007. Sampel tahun 2008 tidak disertakan karena pengaruh krisis ekonomi global yang akan mempengaruhi transaksi saham.

2. Perusahaan yang mempunyai anggota independent dalam komisaris dan komite auditnya.

3. Data Trading Volume Activity dan Laporan Laba Tahunan 2004-2006 lengkap.

4. Perusahaan tidak mempunyai pengumuman lain pada periode window yaitu 2 hari sebelum dan 2 hari sesudah pengumuman laba serta periode non window. Hal ini untuk menghindari adanya confounding effect akibat pengumuman lain seperti merger, akuisisi, right issue, dan stock split. Non event 
window berdasar penelitian sebelumnya, ditentukan 2 hari menjelang 4 minggu sebelum publikasi laporan keuangan (Kanageratnam, 2007)

Reaksi pasar dalam penelitian ini adalah volume perdagangan saham (Trading Volume Activity/TVA). Volume perdagangan saham diukur berdasarkan Trading Volume Activity (TVA). Penelitian Chae (2002) menunjukkan bahwa asimetri informasi secara konsisten berhubungan dengan volume perdagangan saham di sekitar pengumuman laba. Rumus untuk menghitung Trading Volume Activity (TVA):

Jumlah saham perusahaan $\mathrm{i}$ TVA $_{\text {it }}=\frac{\text { yang diperdagangkan pada waktu } \mathrm{t}}{\begin{array}{l}\text { Jumlah saham perusahaan } \mathrm{i} \\ \text { yang beredar pada waktu } \mathrm{t}\end{array}}$

Variabel dalam penelitian ini terdiri dari variable dependen dan variable independent. Variabel dependen merupakan selisih rata-rata trading volume activity periode window (4 hari yang terdiri dari 2 hari sebelum dan 2 hari sesudah pengumuman laba) dengan rata-rata trading volume activity periode non window (2 hari). Periode non window diambil 2 hari perdagangan menjelang 4 minggu sebelum pengumuman laba (Kanagaretnam dkk, 2007). Variabel independen terdiri dari prosentase anggota independen dalam dewan komisaris.

Besar variabel Y ditunjukkan dengan selisih volume perdagangan saham periode window dengan non-window. Sedangkan variabel prediktor adalah prosentase anggota Komisaris independen dan komite audit.
Pengujian statistik untuk hipotesis pertama ini menggunakan alat uji multiple regresi Alfa $(\alpha)$ ditentukan 5\%. Apabila nilai $t$ variabel independen, $\mathrm{p}$ valuenya $\leq 5 \%$ maka hipotesis nol ditolak. Persamaan yang digunakan untuk pengujian hipotesis adalah:

TVA $w-$ TVA nw $=\mathrm{a}+\mathrm{bKI}+\mathrm{cKAI}+\mathrm{e}$

Dimana,

TVA $\mathrm{w}=$ rata-rata trading volume activity periode window

TVA nw $=$ rata-rata trading volume activity non window

KI $=\%$ anggota komisaris independen

$\mathrm{KAI}=\%$ anggota komite audit independen

\section{HASIL ANALISIS DAN PEMBAHASAN}

Penelitian ini menguji reaksi pasar terhadap pengumuman Laba pada perusahaan yang ada komisaris independen dan komite audit independen. Pengujian hipotesis dalam penelitian ini untuk mengetahui ada tidaknya pengaruh keberadaan anggota komisaris independen terhadap penurunan asimetri informasi di sekitar tanggal pengumuman laba. Reaksi pasar tersebut ditunjukkan dengan adanya variabel $\mathrm{Y}$ yang didapat dari selisih volume perdagangan saham perusahaan sampel selama event window dengan non window.

Berdasarkan kriteria pengambilan sampel yang telah ditentukan, maka diperoleh sebanyak 86 sampel akhir. Perusahaan-perusahaan sampel tersebut tersebar dalam berbagai kelompok bidang usaha. Tabel berikut menyajikan kriteria pengambilan sampel yang digunakan dalam penelitian ini: 
Kriteria Sampling

\begin{tabular}{|c|c|c|c|c|}
\hline Keterangan & 2004 & 2005 & 2006 & $\begin{array}{c}\text { Total } \\
\text { Sampel }\end{array}$ \\
\hline Total peserta ICMD 2007 & & & & 343 \\
\hline Perusahaan yang listing di tahun 2003-2006 & & & & (61) \\
\hline Perusahaan yang tidak memiliki anggota & - & - & - & $(60)$ \\
\hline \multicolumn{5}{|l|}{ Independen dalam komisaris dan komite audit } \\
\hline Total Perusahaan & & & & 222 \\
\hline Keterangan & 2004 & 2005 & 2006 & $\begin{array}{c}\text { Total } \\
\text { Sampel }\end{array}$ \\
\hline Total Perusahaan & & & & 222 \\
\hline $\begin{array}{l}\text { Data tidak lengkap (tidak ada data aktivitas } \\
\text { saham harian dan saham beredar, laporan } \\
\text { keuangan tidak dipublikasikan di internet) }\end{array}$ & 192 & 196 & 192 & \\
\hline $\begin{array}{l}\text { Perusahaan yang mempunyai pengumuman lain } \\
\text { pada periode window dan non-window }\end{array}$ & - & - & - & \\
\hline Total sampel & 30 & 26 & 30 & 86 \\
\hline
\end{tabular}

Sumber: Data

Hasil Uji Pengaruh Komisaris Independen terhadap Asimetri Informasi Pengujian hipotesis pertama dilakukan untuk menguji apakah terdapat pengaruh keberadaan anggota komisaris independen terhadap penurunan asimetri informasi di sekitar tanggal pengumuman laba pada perusahaan yang masuk dalam ICMD 2007, berdasarkan volume perdagangan saham. Langkah awal yang harus dilakukan adalah menghitung nilai selisih rata-rata Trading Volume Activity (TVA) pada periode window dengan nonwindow sebagai indikator volume perdagangan saham untuk masing-masing sampel. Periode window dihitung dengan merata-rata volume perdagangan saham pada 2 hari sebelum dan sesudah tanggal pengumuman laba tahunan perusahaan. Periode non-window dihitung dengan merata-rata volume perdagangan saham pada 2 hari menjelang 4 minggu sebelum tanggal pengumuman laba tahunan perusahaan. Periode window dan nonwindow ini dikurangkan untuk mendapat selisih TVA, yang merupakan proksi dari asimetri informasi pada penelitian ini.
Kemudian menghitung prosentase anggota independen dalam komisaris dengan cara membagi jumlah anggota independen dengan total anggota dewan komisaris. Hal ini juga dilakukan untuk memperolah data Prosentase Komite Audit Independen. Data ini didapat dari company profile di internet.

Sebelum dilakukan pengujian hipotesis pertama, terlebih dahulu dilakukan pengujian normalitas untuk mengetahui apakah data yang akan diuji tersebut sudah atau tidak terdistibusi normal. Pengujian normalitas data selisih Total Volume Activity (TVA), prosentase Komisaris Independen ini dilakukan dengan menggunakan One Sample Kolmogorov-Smirnov Test, Hasilnya Ketiga p-value variabel di atas lebih kecil dari level of significance sebesar 0,05. Sehingga untuk dilakukan pengujian, data tersebut perlu dinormalkan dengan metode Ln. Setelah dinormalkan, dapat diketahui bahwa variabel dependen (Y), yaitu TVA window - non window telah terdistribusi normal. Hasil pengujian tersebut menyatakan bahwa $p$-value lebih besar dari level of significance sebesar 0,05. Yaitu 0,58 untuk TVA window - non window dan 0.68 untuk 
Komisaris independenI. Prosentase Komite Audit Independen menunjukkan p-value sebesar 0.000. Hal ini berarti data tidak normal karena lebih kecil dari $\alpha 0,05$. Untuk variabel $\mathrm{X}_{2}$ ini ketidaknormalan disebabkan perusahaan-perusahaan sampel telah menerapkan ketentuan dalam Surat Edaran Bapepam, yang mensyaratkan jumlah anggota komite audit independen minimal 3. Sebagian besar perusahaan sampel, menerapkan 3 anggota komite audit, dengan 1 anggota komite audit independen yang berasal dari komisaris independen. Kemiripan antara data satu dengan yang lain inilah yang menyebabkan data Prosentase Komite Audit Independen tidak dapat dinormalkan.

Oleh karena itu dilakukan uji hipotesis pertama dengan regresi sederhana. Hasilnya variabel independen yaitu Komisaris Independen (KI) signifikan. Hal ini dapat dilihat dari probabilitas signifikansi untuk Prosentase KI sebesar 0,006 yang di bawah 0,05 . Dengan demikian $\mathrm{H}_{01}$ ditolak Sehingga bisa diambil kesimpulan bahwa keberadaan anggota Komisaris Independen berpengaruh terhadap asimetri informasi di sekitar tanggal pengumuman laba.

Hasil Uji Pengaruh Komite Audit Independen terhadap Asimetri Informasi

Karena data tidak berdistribusi normal maka hipotesis kedua diuji dengan Chi Square. Berdasar hasil uji Chi Square untuk variabel independen yaitu Komite Audit Independen (KAI) tidak signifikan. Hal ini dapat dilihat dari probabilitas signifikansi untuk Prosentase KAI sebesar 0,085 . Oleh karena nilai signifikansi di atas 0.05 , dengan demikian bisa diambil kesimpulan bahwa keberadaan Komite Audit tidak memiliki hubungan korelasi terhadap asimetri informasi di sekitar tanggal pengumuman laba.

Untuk memguatkan uji di atas, dilakukan juga uji beda. Dalam uji beda ini diperlukan Sampel dari perusahaan yang tidak terdapat anggota independen dalam Komite Auditnya. Agar sesuai proporsi, dipilih 26 sampel perusahaan secara acak dan kemudian dibandingkan dengan 26 perusahaan yang terdapat anggota independen dalam komite auditnya. Keseluruhan sampel yang akan dibandingkan ini dihitung TVA windownonwindownya. Kemudian dilihat apakah data telah distribusi dengan normal dengan menggunakan One Sample KolmogorovSmirnov Test. Berdasarkan pengujian ini terlihat bahwa data TVAwin-nonwin perusahaan yang tidak ada komite audit tidak terdistribusi normal. $P$-value variabel di atas lebih kecil dari level of significance 0,05 . Sehingga untuk dilakukan pengujian, data tersebut perlu dinormalkan dengan metode Ln. Setelah dinormalkan hasilnya $p$ value $(0,095)$ lebih besar dari level of significance sebesar 0,05 .

Hasil pengujian hipotesis ini diuji dengan independent $\mathrm{t}$ tes. Terlihat dari output SPSS probabilitas 0,072. sehingga dapat diambil kesimpulan bahwa hipotesis tidak dapat ditolak atau memiliki variance yang sama. Jadi tidak terdapat perbedaan penurunan asimetri informasi di sekitar tanggal pengumuman laba antara perusahaan yang mempunyai anggota komite audit independen dengan perusahaan yang tidak mempunyai anggota komite audit independen.

\section{PENUTUP}

\section{Kesimpulan}

Hasil penelitian ini menunjukkan bahwa keberadaan Komisaris Independen memiliki pengaruh terhadap penurunan asimetri informasi di sekitar tanggal pengumuman laba. Hal ini menunjukkan bahwa komisaris independen merupakan sentral mekanisme kontrol internal perusahaan dalam melakukan pengawasan terhadap manajer. Hasil penelitian ini sesuai 
dengan penelitian sebelumnya yang dilakukan Fama (1980), Ajinkya dkk; Karamanou dan Vafeas; Klein; dalam Kanagaretnam (2007) yang menunjukkan bahwa Dewan Komisaris yang memonitor manajemen lebih efektif, akan meningkatkan kualitas dan frekuensi informasi yang diterbitkan manajemen.

Sebaliknya keberadaan Komite Audit Independen tidak berpengaruh dan tidak memiliki korelasi terhadap penurunan asimetri informasi di sekitar tanggal pengumuman laba. Hal ini menandakan keberadaan komite audit tidak meningkatkan kualitas pelaporan keuangan dan fungsifungsi yang diemban belum dijalankan secara optimal. Tidak konsisten dengan temuan penelitian Klien (2001); DeFond dan Jiambalvo (1991); McMulen (1996); Beasly dan Salterio (2001); McMullen dan Raghunandan (1996). Demikian pula tidak terdapat perbedaan yang signifikan terkait penurunan asimetri informasi pada perusahaan yang memiliki Komite Audit Independen dengan yang tidak. Fungsi yang belum optimal mengakibatkan kurang dipercayanya komite audit oleh investor. Hasil ini mendukung penelitian yang dilakukan oleh Beasley (1996); Kalbers (1992); Crowford (1987) di dalam McMullen (1996) dan juga Menon dan Williams (1994).

Keterbatasan penelitian ini karena hanya mendasarkan informasi yang ada di BEI dan tidak menggunakan tambahan informasi dari sumber lain serta sample yang diambil atas dasar purposive sampling hanya 3 tahun. Sehingga penelitian lebih lanjut dapat memperluas sample dan informasi di luar BEI dan periode waktu yang lebih panjang serta variable penurunan asimetri informasi yang lain.

\section{Saran}

Berdasarkan hasil yang diperoleh, penelitian ini dapat memberikan saran kepada perusahaan maupun investor. Perusahaan disarankan agar lebih meningkatkan kualitas pelaporannya dengan meningkatkan kinerja komisaris dan mengoptimalkan peranan komite audit yang selama ini masih dipandang kurang dalam benak investor. Bagi investor, agar mendapat informasi yang benar-benar informatif, harus mempertimbangkan keberadaan komisaris independen dan komite audit independen. Sehingga dengan informasi tersebut, diharapkan investor tidak mengambil kesalahan dalam bereaksi di pasar modal.

\section{DAFTAR PUSTAKA}

Arifin, Z. .(2003). Pengaruh Corporate Governance terhadap Reaksi Harga dan Volume Perdagangan Pada Saat Pengumuman Earnings. Simposium Nasional Akuntansi VI. 16-17 Oktober 2003, Surabaya. 614-621.

Atiase, R., dan Bamber, L.S., (1994). Trading Volume Reactions To Annual Accounting Earnings Announcements. Journal of Accounting and Economics 17, pp 309-329

Ball, Ray dan P. Brown, (1968). An Empirical Evaluation of Accounting Income Numbers, Journal of Accounting Research (autumn), pp 159-178

Bandi dan J Hartono (1999). Perilaku Reaksi Harga dan Volume Perdagangan Saham terhadap Pengumuman Dividen. Simposium Nsional Akuntansi II, September, Surabaya.

Beasley, M. S. (1996). An Empirical Analysis of the Relation Between the Board of Director Composition and Financial Statement Fraud. The 
Accounting Review, 71, pp 443465.

Beasly, M. S. dan Salterio, S. E. (2001). Relation Between Board Characteristics and Voluntary Improvements in Audit Committee Composition and Experince. Contemporary Accounting Research, Vol. 18 (4), 539-70.

Chau, Gerald, dan Leung, Patrick (2006). The Impact of Board Composition and Family Ownership on Audit Commitee Information : Avidence from Hongkong. Journal of International Accounting, Auditing, and Taxation, 15. pp 1-15

Chae, Joon (2002). Timing Information, Information Asymetry, and Trading Volume. http://www.ssrn.com.

Dechow, Patricia M. (1995). Detecting Earnings Management. The Accounting Review, April Vol. 70 (2), pp.351-373

DeFond, M. L. dan Jiambalvo, J. (1994). Debt Convenant Violation and Manipulation of Accruals. Journal of Accounting\&Ecconomics, 17 pp 145-176.

Eng, dan Mak (2003). Corporate Governance and Voluntary Disclosure. Journal of Accounting and Public Policy, 22 (2003) 325345.

Fama, E.F., (1980). Agency Problems and Theory Of The Firm. Journal of Political Economy, Vol. 88 (2), 288-307.

Fama, E. F., \& Jensen, M. C. (1983). Agency Problems and Residual Claims. Journal of Law and Economics, (June), pp 327-349.
Forum for Corporate Governanace in Indonesia (FCGI). Corporate Governance di Indonesia. http://www.fcgi.or.id.

Hua, Chi Yun; Min-Li Yao; Wen Chih Lee; Wei-Ming Chine (2006). Information Asymmetry at Merge and Acquisition- An Investigation on Firm in The Electric Industry. Working Paper.

Jensen, M. C. dan W. H. Meckling (1976). Theory of the Firm: Managerial Behavior Agency Costs and Ownership Structure. Journal of Financial Economics, Vol. 3 (4), 305-360.

Kalbers, L. P. (1992). An Examination of the relationship between audit committees and external auditors. The Ohio CPA Journal, December 1992, pp. 19-27.

Kanagaretnam, Kiridaran; Gerald J Lobo; Dennis J Whalen. (2007). Does Good Corporate Reduce Information Asymmetry Around Quarterly Earnings Announcements? Journal of Accounting and Public Policy, 26, pp 497-522.

Klien, A. (2001). Audit Committee, Board of Director Caracteristics and Earnings Management. Journal Accounting and Economics 33, pp. 375-400.

Majalah SWA (2006). Edisi 26/XXII/11-20 Desember 2006.

McMullen, D. A. dan Raghunandan, K. (1996). Enhancing Audit Committee Effectiveness. Journal of Accounting, Agustus, pp 88-101.

McMullen, D.A. (1996). Audit Committee Performance: An Investigation of 
the Consequences Associated with Audit Committees. Auditing: A Journal of Practice \& Theory, Vol. $15,(1)$, pp 88-103.

Menon, Krishnagopal and Williams, J. D. (1994). The Use Of Audit Commitees for Monitoring. http://www.ssrn.com.

Moksin, Pengiran Haji (2007). Corporate Governance and Its Impact On A Firm"s Equity Price and Cost of Capital. Jakarta: Makalah 15 th AFA Conference.

Setiawan, Doddy dan Sitti Subekti (2005). Pengujian Efisiensi Pasar Bentuk Setengah Kuat Secara Keputusan: Analisis Pengumuman Dividen Meningkat (Studi Empiris pada Bursa Efek Jakarta Selama Krisis Moneter). Jurnal Riset Akuntansi Indonesia, Vol. 8, (2), 121-137.

Sunarto (2003). Corporate Governance dan Kinerja Saham. Fokus Ekonomi. Vol. 2 (3), 240-257.
Ujiyantho, Muh. Arief dan Bambang Agus Pramuka (2007). Mekanisme Corporate Governance, Manajemen Laba, dan Kinerja Keuangan. Simposium Nasional Akuntansi X. 26-28 Juli 2007, Makassar.

Widayanti, Nita (2005). Pengaruh Publikasi Laporan Keuangan Tahunan terhadap Aktivitas Volume Perdagangan Saham dan Variabilitas Tingkat Keuntungan Saham. Skripsi, Fakultas Ekonomi Universitas Sebelas Maret Surakarta.

Wuryanti, Tri (2004). Analisis Reaksi Pasar terhadap Informasi Laba Pada Saat Krisis Moneter: Security Return Variability dan Trading Volume Activity. Skripsi, Fakultas Ekonomi Universitas Sebelas Maret Surakarta. 